\title{
The Effect of Organizational Structure, Work Motivation and Decision Making on Vendor's Employee performance at Automotive Distributor in Indonesia
}

\author{
Oloan Situmorang ${ }^{1}$, Mukhneri Mukhtar ${ }^{2}$, Mahmuddin Yasin $^{3}$ \\ \{oloansitumorang_7647140261@mahasiswa.unj.ac.id ${ }^{1}$, mukhneri@unj.ac.id², mahmuddinyasin@unj.ac.id ${ }^{3}$ \} \\ Student of Universitas Negeri Jakarta, Jakarta, Indonesia ${ }^{1}$, Permanent Professor of Universitas \\ Negeri Jakarta, Jakarta, Indonesia ${ }^{2}$, Non-Permanent Professor of Universitas Negeri Jakarta, \\ Jakarta, Indonesia ${ }^{3}$
}

\begin{abstract}
This study aim to determine and analize the effect of organizational structure, work motivation, and decision making on vendor's employee performance at Automotive Distributor in Indonesia. This study uses quantitative research method. The respondents area 100 employees, with sampling random technique. The questionaire of organizational structure, work motivation, decision making and employee performance were validated with the product moment correlation formula, while reliability was measured by the Alpha Cronbach formula. Tested of the hypothesis in this study use of the path analysis. The research result of the study found that : (1) The organizational structure affects employee performance positively while it has no direct effect on employee performance through decision making, (2) The work motivation affect employee performance positively while it has no direct effect on employee performance through decision making, (3) The decision making affect employee performance positively, (4)The organizational structure affect decision making positively, (5) The work motivation affect decision making positively, and (6) The organizational structure affect work motivation positively. The result of the study show that the effort to improve the employee performance can be done by implementing the effective organizational structure, enhancing work motivation and strengthening decision making.
\end{abstract}

Keyword: Organizational Structure, Work Motivation, Decision Making, Employee Performance.

\section{Introduction}

In an increasingly competitive industrial era, especially the automotive industry, every company that wants to win the competition in the business world will pay full attention to the quality of human resources. In this case, the employer company has full attention to ensure the logistics partners can support their business well. So the employer has a role to ensure logistics vendors can run their services efficiently.

Employees are important resources for the company, because they have the expertise, energy and creativity that are needed by the company to achieve its goals. In a dynamic business environment, by doing business with vendors, each vendor company requires an organizational structure that is able to provide the best performance and be able to build highly motivated employees and agile in running their business processes. Through an optimal organizational structure, high employee motivation, effective decision making process will provide value to the organization through performance. 
PT Toyota - Astra Motor , the VLD (Vehicle Logistics Division), has the role of carrying out vehicle logistics operations, namely handling new vehicles, starting from factory receipts, installing accessories and distributing vehicles to all dealers in Indonesia while maintaining vehicle quality (fresh from the oven) and safe operation (safety operation) for all stakeholders. Various functions of the business units in the Logistics Division. In carrying out its roles and responsibilities, VLD partners with logistics vendors / suppliers to carry out some of its functions.

Internally, VLD operate the operation with the Toyota way philosophy. Toyota way is DNA in Toyota Business. The two pillars of the Toyota way are respect for people and kaizen (continuous improvement). Each pillar is translated into cultural values that are applied daily, especially in the innovation behavior of every employee who supports Toyota's business.

From the results of evaluating the performance of existing vendors, it is still found that achievement has not been achieved optimally, such as still not achieving the timely delivery of new vehicles from the factory to the dealer (on time delivery), and there are still defects in new vehicles (damage ratio) during the process delivery of new vehicles. Performance of vendor employees has an important role to achieve the performance of the Toyota-Astra Motor which will ultimately impact on VLD performance.

In an effort to improve employee performance, it needs to be supported by a solid and professional organizational structure, because in practice work specialization, spezialization of work, departmentalization, comand chain, span of control, centralization, decentralization, and formalization has direct and indirect effects on the amount of work, quality of work, knowledge breadth regarding work and skill, authenticity of the idea of willingness to cooperate with others ( fellow members of the organization ), awareness and trustworthiness, enthusiasm for carrying out new tasks, and personality.

\section{Literature Review}

\subsection{Employee Performance}

According to Colquitt states Job performance is formally as the value of the set of employee behaviour that contributes either positively or negatively to organizational goal achievement. It has three components: 1) task performance, or transformation of resources into goods and services; 2) citizenship behaviours, or voluntary employee actions that attribute to the organization; and 3) counterproductive behaviour[1]. Gibson et al. states "performance refers to the level of success in implementing the task and the ability to achieve the goal set. Otherwise good performance and successful if the desired goal can be achieved with good quality[2]. According to Cascio describes performance as a way to ensure that individual or team workers know what is expected of them and remain focused on effective performance by paying attention to objectives, measures and assesments[3].

According to Gomes that indicators of employee performance are (1) Quantity of work: the amount of work done in specified period; (2) Quality of work: The quality of work achieved is based on conditions of sustainibility and readyness; (3) Job knowledge: The extent of knowledge about the jobs and its skills; (4) Creativeness: Authenticity of ideas arising from actions to solve problem that arise; (5) Cooperation: Willingness to cooperate with others (fellow members of the organization ); (6) Dependability : Awareness and trustworhiness in terms of attendance and completion of work on time ; (7) Initiative: Enthusiasm to carry out new task in enlarging their responsibiities; (8) Personal qualities : Regarding personality, leadership, hospitality and personal integrity[4]. 


\section{2 Organization Structure}

Various definitions of organizational structure have been put forward by management experts. According to Shane that there are three components to the organizational structure; namely (1) shows formal reporting channels, (2) identifies the grouping of individuals into departments into the organization as a whole; and (3) includes system designs to ensure smooth communication, coordination and integration of cross-departmental efforts[5]. Stephen also agree that the organizational structure describes how work tasks are formally grouped and coordinated. According to him there are also six key elements that need to be considered in designing the organizational structure, namely: "1) work specialization, 2) grouping departments, 3) chain of command, 4) scope of control, 5) centralization and decentralization, 6) formalization[6]. According to Daft Richard, there are 3 main requirements that must be considered when determining the organizational structure, namely 1 ) The organizational structure must show formal relations between employees, including the level of hierarchy, and the range of control of managers and supervisors; 2) Organizational structure establishes a work group for employees, merging groups within departments, and integrating departments into the company as a whole; and 3) Organizational structure includes system planning to ensure effective communication, good coordination and integration between departments[7].

According to Jerald, the organizational structure is "the formal configuration of individuals and groups with respect to the allocation of tasks, responsibilities, and authority within the organization," (formal configuration of individuals and groups within the allocation of duties, responsibilities and authority within organization)[8]. According to Shane, the organizational structure is defined as "the division of labor as well as the conditions of conditions, communication, workflow, and formal power that direct organizational activities," (division of work and coordination patterns, communication, formal employment and power lines related to organizational activities)[5].

To deepen the understanding of organizational structure, it is necessary to understand various organizational structure designs that can be done through several approaches. Approach

\section{3 Motivations}

According to Luthans, "Motivation as a process that starts with the physiological of psychological deficiency or needs that activates behavior or a drive that is aimed at a goal or incentive". Furthermore Luthans that in a motivation system consists of three elements that interact and are interdependent, namely: needs (needs), drives (incentives), incentives (incentives)[9], while Lawrence, Nohria states, there are 4 impulses (four) drive) that applies to everyone, namely drive to acquire (drive to reach), drive to bond (drive to bond) and drive to learn (drive to learn)[10].

Shane, Steven L.Mc states motivation refers to forces within a person that affects the direction, intensity, and persistence of voluntary behavior[5]. Motivation according to Latham and Pinder, motivation is a set of energetic forces that originate both within as well as beyond an individual's being, to initiate work-related behavior, and to determine its form, direction, intensity and duration[11].

The theory that is often used by experts in conducting research on motivational problems is the theory that has to do with human needs. One theory related to motivation is the theory of needs developed by Maslow. Abraham Maslow developed a theory of motivation known as (hierarchy of needs). Maslow in Burton holds that the theory of the hierarchy of human needs can be used to describe and predict motivations. Motivation theory is based on two assumptions. First, what someone's needs have been fulfilled. Second, needs are a hierarchy of interests. In this theory a classification of needs is proposed which consists of five groups of human needs that form a 
hierarchy of needs, namely the first physical needs (physiological Neds), the physical needs of a person are in dire need of food, clothing and shelter. After the activity fulfillment needs are met and has decreased, then the need for security increases. When the physical needs for food, clothing, shelter have been met, then a person switches to the need to associate with the community, the need for affiliation with others, the need to find meaningful relationships[11].

Synthesis of motivation is the size of the work done by an employee in carrying out their duties with indicators of employee motivation, including: (1) employee's desire to get good performance, (2) employee's drive to get awards and recognition for the work performance achieved, (3 ) encouragement of employees to get a sense of security at work, (4) relationships between employees with fellow workers at work, and (5) needs of employees are met (6) secondary needs are met.

\subsection{Decision Making}

According to Schemerhorn defines decision making as "the process of choosing a course of action to deal with a problem or opportunity". Definition of decision making is a series of process of selecting an action to face a problem or opportunity[12]. According to Glinow, Von , "decision making is a concious process of making choices among alternatives with the intention of moving toward some desired state of affairs". Mcshane and Vin Glinow state that there are 6 steps in decision making. The first step is to identify the problem and acknowledge an opportunity. The second involves several parties how to choose the best a decision process. The third step is develop alternative solution. The fourth step is choose the best alternative. The fifth step is implement the selected alternatives. The six step is evaluate decision outcome[5].

Stages in decision making are: 1) identifying problems, 2) developing existing alternatives, preparing potential alternative solutions; 3 ) evaluation of alternatives that meet the criteria; 4) choose alternatives that have maximum value; 5) implement the appropriate solution.

From the description above, decision making synthesis is the process of determining the decision to take action to take into account opportunities and risks with the aim of improving organizational performance with decision making indicators including information gathering, information processing, alternative search, alternative assessment, decision making, implementation decision, evaluation of the decision.

\section{Methods}

The method used in this study is to use a survey method that is conducting research directly into the field. Data collection tool used was a questioner (questionnaire). With this data collection tool data can be obtained in accordance with the theme of the research. Research data is captured using a questionnaire developed by researcher and given to samples from the popuation.Respondent of this research are 100 employees. Samples were determined using cluster random sampling techniques. Instruments of organizational structure, work motivation and performance are validated by product moment coorelation, while reliability is measured by Cronbach's Alpha. Data is analyzed using path analysis techniques.

\section{Research Result and Discussion}

Testing Hypothesis Pathway In Hypothetic Models py1, py2, py3, p31, p32, p21. Path coefficients in the hypothetical model of the study are py1, py2, py3, p31, p32, p21, in determining the magnitude of the path in a hypothetical model the study is obtained by 
determining the magnitude of the path coefficient value, and then the path coefficient significance test is continued.

\subsection{Model Testing}

\subsubsection{Structural Path Coefficient 1}

Causal relationships between variables in sub-structural 1 consist of one endogenous variable, $\mathrm{Y}$ and three exogenous variables, namely $\mathrm{X} 1, \mathrm{X} 2$, and $\mathrm{X} 3$. From the results of processing the structural path coefficient 3 data as follows:

Table 1. Path coefficient and Structural Significance Test 1

\begin{tabular}{|c|c|c|c|c|c|c|}
\hline \multicolumn{7}{|c|}{ Coefficients $^{\mathrm{a}}$} \\
\hline \multirow{2}{*}{\multicolumn{2}{|c|}{ Model }} & \multicolumn{2}{|c|}{$\begin{array}{l}\text { Unstandardized } \\
\text { Coefficients }\end{array}$} & \multirow{2}{*}{$\begin{array}{c}\begin{array}{c}\text { Standardized } \\
\text { Coefficients }\end{array} \\
\text { Beta }\end{array}$} & \multirow[t]{2}{*}{$\mathrm{T}$} & \multirow[t]{2}{*}{ Sig. } \\
\hline & & $\mathrm{B}$ & Std. Error & & & \\
\hline & (Constant) & 77.086 & 5.969 & & 12.914 & .000 \\
\hline \multirow{3}{*}{1} & Organization structure & .188 & .044 & .395 & 4.284 & .000 \\
\hline & Work motivation & .123 & .042 & .269 & 2.917 & .004 \\
\hline & Decision making & .135 & .045 & .365 & 3.772 & .002 \\
\hline & endent Variable: en & forn & & & & \\
\hline
\end{tabular}

Table 2. Coefficient terminated R Square for structure 1

\begin{tabular}{|c|c|c|c|}
\hline \multicolumn{4}{|c|}{ Model Summary } \\
\hline Model & R Square & $\begin{array}{l}\text { Adjusted R } \\
\text { Square }\end{array}$ & $\begin{array}{l}\text { Std. Error of the } \\
\text { Estimate }\end{array}$ \\
\hline 1 & $.564^{\mathrm{a}}$ & .297 & 2.911 \\
\hline
\end{tabular}


From the path coefficient table, the analysis results obtained by the value of the path coefficient pyl of 0.395 and tcount $=4.284$, with ttable $(0.05: 98)=1.98$, so tcount $=4.284$ is greater than ttable (4.28> 1.98), reject $\mathrm{H}_{0}$, it means that the variable $\mathrm{X}_{1}$ has a direct effect on the variable $\mathrm{Y}$. Thus it is evident that the organizational structure has a direct positive effect on employee performance.

The analysis results obtained by the value of the py 2 path coefficient of 0.269 and tcount 2.917 , with ttable $(0.05: 98)=1.81$, so that tcount $>$ ttable, reject $\mathrm{H}_{0}$, meaning that the variable $\mathrm{X}_{2}$ has a direct positive effect on the variable $\mathrm{Y}$. Thus it is evident, that work motivation has a direct positive effect on employee performance.

The results of the analysis obtained the path coefficient value of $\mathrm{py}_{3}$ of 0.365 and tcount, 3.772 with ttable $(0.05: 98)=1.98$, so tcount $>$ ttable, reject $\mathrm{H} 0$, meaning that the variable $\mathrm{X}_{2}$ has a direct positive effect on the variable Y. Thus it is evident, that taking the decision has a direct positive effect on employee performance. From the results of the analysis, the coefficient of determination obtained by 0.318 so that it can be stated that the organizational structure, work motivation and decision making have a direct positive effect on employee performance.

\subsubsection{Structural path coefficient 2}

Causal relationships between variables in sub-structural 2 consist of one endogenous variable, $\mathrm{X}_{3}$ and two exogenous variables, $X_{1}$ and $X_{2}$. From the results of data processing the structural path coefficient 1 as follows:

Table 3. Path coefficient and Structural Significance Test 2

\begin{tabular}{|c|c|c|c|c|c|c|}
\hline \multicolumn{7}{|c|}{ Coefficients } \\
\hline \multirow{2}{*}{\multicolumn{2}{|c|}{ Model }} & Unstanc & Irdized & & $\mathbf{T}$ & Sig. \\
\hline & & B & Std. Error & Beta & & \\
\hline \multirow{3}{*}{1} & (Constant) & 73.937 & 4.346 & & 17.011 & .000 \\
\hline & Organization structure & 189 & .044 & 396 & 4.308 & .000 \\
\hline & Work motivation & 122 & .042 & 267 & 2.899 & .005 \\
\hline
\end{tabular}

Table 4. Coefficient terminated R Square for structure 1

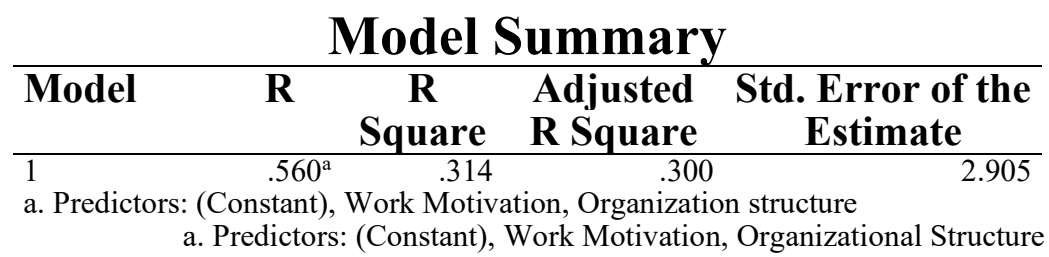

From the path coefficient table, the analysis results obtained the path coefficient $\mathrm{p}$ value of 0.396 and tcount 4.308 , with ttable $(0.05: 98)=1.98$, so tcount $>t_{\text {table, }}$, reject $\mathrm{H} 0$, meaning that the variable $\mathrm{X}_{1}$ has a positive effect on the $\mathrm{X} 3$ variable. It is thus proven that the organizational structure has a direct positive effect on decision making. 
The results of the analysis obtained the path coefficient $\mathrm{p}_{32}$ of 0.267 and tcount 2.898 , with ttable $(0.05: 98)=1.98$, so $t_{\text {count }}>\mathrm{t}_{\text {table }}$, reject $\mathrm{H}_{0}$, meaning that the $\mathrm{X}_{2}$ variable has a pos itive direct effect on the $\mathrm{X}_{3}$ variable. Thus it is proven, that work motivation has a direct positive effect on decision making.

From the results of the analysis, the coefficient of determination obtained by 0.314 so that it can be stated that the organizational structure and work motivation have a direct positive effect on decision making.

\subsubsection{Structural Path coefficient 3}

Causal relationships between variables in sub-structural 3 consist of one endogenous variable, $\mathrm{X}_{2}$ and one exogenous variable, $\mathrm{X}_{1}$. From the results of processing the structural path coefficient 3 data as follows:

Table 4. Path coefficient and Structural Significance Test 3

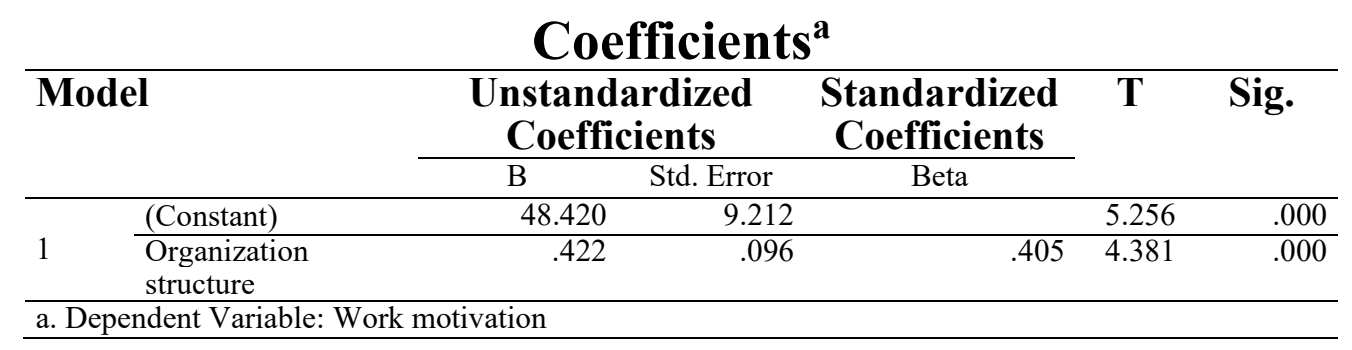

Table 5. R Square terminated coefficient for structure 3

\begin{tabular}{|l|l|l|l|l|}
\hline \multicolumn{5}{|c|}{ Model Summary } \\
\hline Model & R & $\begin{array}{l}\text { R } \\
\text { Square }\end{array}$ & $\begin{array}{l}\text { Adjusted } \\
\text { R Square }\end{array}$ & $\begin{array}{l}\text { Std. Error } \\
\text { of the } \\
\text { Estimate }\end{array}$ \\
\hline 1 & $.405 \mathrm{a}$ & .164 & .155 & 6.971 \\
\hline $\begin{array}{l}\text { a. Predictors: (Constant), } \\
\text { Organization Structure }\end{array}$ & & & & \\
\hline
\end{tabular}

From the path coefficient table, the analysis results obtained $\mathrm{p}_{21}$ path coefficient of 0.422 and tcount $=4.381$, with $t_{\text {table }}(0.05: 98)=1.98$, so $t_{\text {count }}>t_{\text {table }}$, reject $\mathrm{H}_{0}$, meaning that the variable $\mathrm{X}_{1}$ has a positive effect on the $\mathrm{X}_{2}$ variable. It is thus proven, that organizational structure has a direct positive effect on work motivation.

From the results of the analysis, the coefficient of determination obtained by 0.164 so that it can be stated that the organizational structure has a direct positive effect on work motivation .

Table 6. Summary of Test Results for Significance of Paths

\section{No. Influence Coefficient df $T_{\text {cout }} t_{\text {table }}$}




\begin{tabular}{ccccccc} 
& Live & Pathway & & & $\boldsymbol{\alpha}=\mathbf{0 , 0 5}$ & $\boldsymbol{\alpha}=\mathbf{0 , 0 1}$ \\
\hline 1 & $\mathrm{X}_{1}$ on $\mathrm{Y}$ & 0,395 & 98 & 4,284 & 1.98 & 2,617 \\
2 & $\mathrm{X}_{2}$ on $\mathrm{Y}$ & 0,269 & 98 & 2,917 & 1.98 & 2,617 \\
3 & $\mathrm{X}_{3}$ on $\mathrm{Y}$ & 0,365 & 98 & 3,772 & 1.98 & 2,617 \\
4 & $\mathrm{X}_{1}$ on $\mathrm{X}_{3}$ & 0,396 & 98 & 4,308 & 1.98 & 2,617 \\
5 & $\mathrm{X}_{2}$ on $\mathrm{X}_{3}$ & 0,267 & 98 & 2,899 & 1.98 & 2,617 \\
\cline { 2 - 6 } 6 & $\mathrm{X}_{1}$ on $\mathrm{X}_{2}$ & 0,422 & 98 & 4,381 & 1.98 & 2,617 \\
\hline
\end{tabular}

Based on the test analysis of the path above, it can be explained the following hypothesis testing:

a. The organizational structure $\left(\mathrm{X}_{1}\right)$ has a positive direct effect on employee performance $(\mathrm{Y})$ and indirectly through decision making $\left(\mathrm{X}_{3}\right)$.

From the results of the path analysis of the influence of organizational structure $\left(\mathrm{X}_{1}\right)$ on employee performance $(\mathrm{Y})$ obtained path coefficient $\rho y 1$ of 0.395 with a tcount of 4.284 , while the value of $t_{\text {table }}=1.98(\alpha=0.05 ; \mathrm{df}=98)$. Because $t_{\text {count }}>t_{\text {table }}$, then $H_{0}$ is rejected, $H_{1}$ is accepted. Thus it can be concluded that the organizational structure has a direct positive effect on employee performance. While the effect of organizational structure $\left(\mathrm{X}_{1}\right)$ on employee performance $(\mathrm{Y})$ through decision making $\left(\mathrm{X}_{3}\right)$ is the result of the path coefficient $\rho \mathrm{y}_{1} \times \mathrm{x}_{3}(0.365) \times(0.396)=(0.145)$.

Thus it can be concluded that the organizational structure has a direct positive effect on employee performance through work motivation.

b. Work motivation $\left(\mathrm{X}_{2}\right)$ has a positive direct effect on employee performance $(\mathrm{Y})$ and indirectly through work motivation (Y).

From the results of the path analysis the effect of work motivation $\left(\mathrm{X}_{2}\right)$ on employee performance $(\mathrm{Y})$ obtained the path coefficient $\rho_{2}$ of 0.269 with a tcount of 2.917 while the value of ttable while $1.98(\alpha=0.05 ; \mathrm{df}=98)$. Because $t_{\text {count }}>t_{\text {table, }}$, then, $\mathrm{H} 0$ is rejected, $\mathrm{H} 1$ is accepted. While the influence of work motivation $\left(\mathrm{X}_{2}\right)$ on employee performance $(\mathrm{Y})$ through decision making $\left(\mathrm{X}_{3}\right)$ is the result of the path coefficient $\rho \mathrm{y}_{2} \times \mathrm{xy}_{3}(0.365) \times(0.267)=$ (0.097).

Thus it can be concluded that work motivation has direct and indirect positive effects on employee performance through work motivation.

c. Decision making $\left(\mathrm{X}_{3}\right)$ has a direct positive effect on employee performance $(\mathrm{Y})$

From the results of the path analysis of the influence of decision making $\left(\mathrm{X}_{3}\right)$ on employee performance $(Y)$, the path coefficient $\rho y_{3}$ is 0.365 , with a tcount of 3.772 , while the value of table $=1.98(\alpha=0.05 ; \mathrm{df}=98)$. Because tcount> ttable, then $\mathrm{H} 0$ is rejected, $\mathrm{H} 1$ is accepted. Thus it can be concluded that decision making has a direct positive effect on employee performance, then $\mathrm{H}_{0}$ is rejected, Thus it can be concluded that decision making has a direct negative effect on employee performance.

d. The organizational structure $\left(\mathrm{X}_{1}\right)$ has a positive direct effect on decision making $\left(\mathrm{X}_{3}\right)$ 
From the results of the path analysis of the effect of organizational structure $\left(\mathrm{X}_{1}\right)$ on work motivation $\left(\mathrm{X}_{3}\right)$ obtained path coefficient $\rho 31$ of 0.396 with a tcount of 4.308 , while the value of $t$ table $=1.98(\alpha=0.05 ; \mathrm{df}=98)$. Because $\mathrm{t}_{\text {count }}>\mathrm{t}_{\text {table, }}$, then $\mathrm{H} 0$ is rejected, $\mathrm{H}_{1}$ is accepted. Thus it can be concluded that the organizational structure has a direct positive effect on decision making.

e. Work motivation $\left(\mathrm{X}_{2}\right)$ has a positive direct effect on decision making $\left(\mathrm{X}_{3}\right)$

Based on the results of the path analysis the influence of work motivation $\left(\mathrm{X}_{2}\right)$ on decision making (X3) obtained path coefficient $\rho_{32}$ of 0.267 with a tcount of 2.899 , while the value of ttable $=1.98(\alpha=0.05 ; \mathrm{df}=98)$. Because $\mathrm{t}_{\text {count }}>\mathrm{t}_{\text {table, }}$, then $\mathrm{H} 0$ is rejected, $\mathrm{H}_{1}$ is accepted. Thus it can be concluded that work motivation has a direct positive effect on decision making.

f. The organizational structure $\left(\mathrm{X}_{1}\right)$ has a positive direct effect on work motivation $\left(\mathrm{X}_{2}\right)$ The statistical hypothesis tested was a positive direct effect on organizational structure $\left(\mathrm{X}_{1}\right)$ on work motivation $\left(\mathrm{X}_{2}\right)$. From the results of the path analysis of the influence of organizational structure $\left(\mathrm{X}_{1}\right)$ on work motivation $\left(\mathrm{X}_{2}\right)$ obtained path coefficient $\rho 21$ of 0.422 with tcount $=4.381$ while the value of ttable $=1.98(\alpha=0.05 ; \mathrm{df}=98)$. Because $\mathrm{t}_{\text {count }}>\mathrm{t}_{\text {table, }}$, then $\mathrm{H}_{0}$ is rejected, $\mathrm{H} 1$ is accepted. Thus it can be concluded that the organizational structure has a direct positive effect on work motivation.

\subsection{Disscusion}

From the results of hypothesis testing shows that there is an effect of organizational structure that has direct and indirect positive effects on employee performance. The more positive the organizational structure, the employee's performance tends to increase. As stated by M.C.Robbins states that a good organizational structure can produce good performance, therefore in an effort to improve performance can be done through strengthening the organizational structure[13]. In an effort to improve employee performance, it needs to be supported by the structure solid and professional organizations, because in practice work specialization, departmentalization, chain of command, range of control, centralization and decentralization, formalization has direct and indirect effects on the amount of work, quality of work, breadth of knowledge about work and skills, authenticity of the idea of willingness to work together with others (fellow members of the organization), awareness and trustworthiness, enthusiasm for carrying out new tasks, and personality

In managing company resources, work motivation has a direct effect on employee performance, because managing employees by increasing organizational authority, delegating tasks, supervising work division can directly influence work quantity, work quality, work effectiveness, work efficiency, and work methods. According to Kreitner that the drive to work effectively can be influenced by decision making, because decision making requires the identification and selection of alternative solutions that lead us to the desired conditions in accordance with organizational expectations[14]. Likewise, according to Glinow , that the process of choice in making a decision, starting from identifying a problem and recognizing an opportunity, involves several parties how to process a decision, identify and develop possible solutions in line with the interests of motivation in the organization[5].

Hypothesis testing results indicate there is an influence of decision making on employee performance. The better the decision making, the better the performance of employees. The proportion of variance in employee performance can be explained by decision making. According to Kreitner decision making requires the identification and selection of alternative solutions that lead us to the desired conditions[14]. According to Glinow, that the choice process in making a 
decision, starts from identifying a problem and recognizing an opportunity, involving several parties how to process a decision, identifying and developing possible solutions[5].

In an effort to improve employee performance, it needs to be supported by decision making, because in practice the choice process in making a decision, starts from identifying a problem and recognizing an opportunity, involving several parties how to process a decision, identifying and developing possible solutions. influence directly and indirectly on the amount of work, quality of work, breadth of knowledge about work and skills, authenticity of the idea of willingness to cooperate with others (fellow members of the organization), awareness and trustworthiness, enthusiasm to carry out new tasks, and personality.

Organizational structure is one of the variables that constantly and stably contributes to decision making. Efforts to reduce decision making can be initiated by improving the organizational structure first. As stated Rahmandana states that the organizational structure in accordance with the company will be more efficient in making decisions in the company[16]. Furthermore, in research conducted by Ridha states that organizational structure affects employee performance improvement, especially supported by the existence of the accuracy of the division of tasks and responsibilities[17]. The results of this study are supported by Robbins which states that: Organizational structure is an organizational control tool that shows the level of delegation of authority from top leadership in decision making which is extreme grouped into two, namely centralization and decentralization[18]. While Lazaroiu also added that: organizational structure is a hierarchical structure that shows an arrangement of the division of responsibilities according to the hierarchical function shown for individual decision making in an organization[19].

The results of hypothesis testing indicate there is an influence of work motivation on decision making. The conclusion shows that the more positive the work motivation, the lower the decision making. The proportion of decision making variance can be explained by work motivation

\section{Conclusion}

Based on the research discussion ,some conclusions can be referred as follows

Organizational structure affects employee performance and indirectly through decision making as mediator. This shows the comparison of employee performance variables can be approved by the organizational structure. The more positive the organizational structure, the better the performance of employees.

Work motivation affects employee performance and indirecty through decision making as mediator. This can be interpreted as employee performance variables that can be approved by work motivation. The better work motivation, the better the employee's performance.

Looks Important. Make decisions making affects on employee performance. This can be interpreted as employee performance variables that can be approved by decision making. The quick the decision making, the better the employee's performance.

The affect the organizational structure on decision making. This shows that these variables make decisions based on organizational structure. The better organizational structure, the more employee decisions are made.

Looks Important. This shows that the employee outcome variable can be approved by decision making. The quick decision making, will impact to the better employee performance.

Relating to the organizational structure and work motivation. This shows the variety of work that can be seen by the organizational structure. Well organizational structure will affect to work motivation . 


\section{Recommendation}

Based on the results of the study showed that motivation is the lowest variable that affect on employee performance.Therefore, in improving the performance of employees, it is necessary to increase and improve motivation by increasing employee motivation to get good performance, increasing employees to get awards and performance to improve their performance, encouraging employees to get a sense of security at work, relationships between employees and participants at work, and the needs of employees are met, secondary needs are met need to improve the organizational system.

In building achievement, it is necessary to strive through giving of insintive and rewarding employees who excel by giving a position on a sturdy chair or giving other awards that can support employee performance.

In increasing motivation, the company supports providing a sense of security at work providing work facilities that meet the needs and work standards that ensure employee safety.

In building employee motivation, the company also supports building harmonious relationships through vertical and horizontal communication, this is because community communication is a strategic factor in building good organizational structure.

Acknowledgements. The researcher would like to thank the leaders and all staff of the PT. Toyota Astra Motor Indonesia of who had helped in the completion of this research.

\section{References}

[1] W. Colquitt, Lepine, Organizational behavior, Improving performance and commitment in the workplace, 6th ed. New York: McGraw-Hill Higher Education, 2019.

[2] J. L. Gibson, J. M. Ivancevich, J. H. Donelly Jr, and R. Konopaske, Organizations, Behavior, Structure, Processes, 14th ed. New York: McGraw-Hill, 2012.

[3] wayne F. Cascio, Managing human resources. London: McGraw-Hill Higher Education, 2015.

[4] F. C. Gomes, Manajemen Sumber Daya Manusia. Yogyakarta: Andi Offset, 2005.

[5] M. A. V. G. Shane, Steven L.Mc, Organizational Behaviour, 4th ed. Australia: McGraw-Hill, 2008.

[6] R. obbins P. Stephen, Organizational Behavior, 7th ed. Australia: Pearson, 2014.

[7] Daft Richard L, Organizational theory and design, Twelfth. Boston: Nelson education, 2015.

[8] G. Jerald, Managing Behavior in Organization, 5th Edition, 5th ed. New Jersey: Pearson educated, 2010.

[9] F. Luthans, Organizational behaviour, 11th ed. 2008.

[10] D. Lawrence, Nohria, How Human Nature Shapes Our Choice. San Fransisco: Harvard Bussiness School, 2002.

[11] G. P. Latham and C. C. Pinder, "Work Motivation Theory and Research at the Dawn of the TwentyFirst Century," Annu. Rev. Psychol., vol. 56, no. 1, pp. 485-516, 2005, doi: 10.1146/annurev.psych.55.090902.142105.

[12] et. al. Schemerhorn, Organizational behavior, Improving performance and commitment in the workplace. 2011.

[13] M. C. Robbins, Sephen P, Management. New Jersey: Pearson educated, 2012.

[14] A. kinicki Kreitner, Robert, Organizational BehavioR. New York: McGraw-Hill, 2010. 
[15] M. Glinow, Von, Organizational Behaviour, 14th ed. New York: McGraw-Hill, 2008.

[16] F. \& W. B. Rahmandana, "Pengaruh Sistem Informasi Manajemen dan Struktur Organisasi Terhadap Efektivitas Pengambilan Keputusan Pada Kantor Pelayanan Bea Cukai Tipe A Belawan,” Manaj. dan Bisnis, 2002.

[17] S. Ridha, "Pengaruh lingkungan, Perilaku, Struktur Organisasi, dan Implementasi Sistem informasi berbasis komputer terhadap kinerja karyawan pemerintah kabupaten sorong," Management, vol. Volume 6, pp. 1-8, 2008.

[18] T. A. J. Robbins, Sephen P, Organizational Behaviour. New Jersey: Pearson educated, 2007.

[19] G. Lazaroiu, "Employee Motivation and Job Performance, Linguistic and philosophical Investigations," vol. 14, pp. 97-102, 2015. 